\title{
Metachronous primary lung cancers: The importance of a lifelong follow up
}

\author{
Zafer KOÇAK ${ }^{1}$ \\ Osman HATIPOĞLU ${ }^{2}$ \\ Dilruba OKUMUS ${ }^{1}$ \\ Gündeniz ALTIAY ${ }^{2}$
}

${ }^{1}$ Department of Radiation Oncology, Faculty of Medicine, Trakya University, Edirne, Turkey

${ }^{1}$ Trakya Üniversitesi Tıp Fakültesi, Radyasyon Onkolojisi Anabilim Dalı, Edirne, Türkiye

${ }^{2}$ Department of Chest Diseases, Faculty of Medicine, Trakya University, Edirne, Turkey

2 Trakya Üniversitesi Tıp Fakültesi, Göğüs Hastalıkları Anabilim Dalı, Edirne, Türkiye
We read with interest the report on the third primary lung cancer by Findik et al. (1). They present the case of a patient who develops a third primary metachronous carcinoma 88 months after the diagnosis of first primary and emphasize the importance of a lifelong follow up after surgery.

The risk of a second or an even third primary lung cancer increases with advances in the detection techniques, therapy, and the continuation of smoking after the resection of lung cancer. However, the occurrence of third primary metachronous lung cancer is very rare. We agree with the observation by Findık et al. that metachronous primary lung cancers may have long survival, which may lead to the development of third primary as seen in the our case.

A 54 year-old man who had a history of two times lobectomy presented with a dyspnea. He had an operation of the left lower lobectomy due to the epidermoid carcinoma of the left lower lobe in 2004. Eight years after the first operation, he developed an epidermoid carcinoma on the right middle lobe treated with a right middle lobectomy. Thirty five months after the second operation, because of a mass on the right lower lobe on computerized tomography, bronchoscopy was performed. On bronchoscopic examination, the distal part of the intermediate bronchus was seen to be occluded totally with a vegetative endobronchial mass. Then, it was decided to use endobronchial electrocautery for debulking the tumor. After the ablation, the tumor was seen to originate from the distal part of the intermediate bronchus and the entrance of the right lower lobe. The stump of the right middle lobe was intact. Its histology was epidermoid carcinoma as the third primary metachronous carcinoma eleven years after the diagnosis of first primary cancer. Then, he received radiation therapy because of very limited pulmonary reserve. However, he died of an acute infective exacerbation of COPD eight months after the diagnosis of third primary.

In the English Language Medical Literature, the development of third metachronous primary lung cancers has been reported in a few studies because

\section{Yazışma Adresi (Address for Correspondence)}

Dr. Zafer KOÇAK

Trakya Üniversitesi Tıp Fakültesi, Radyasyon Onkolojisi Anabilim Dalı, EDIRNE - TURKEY

e-mail: zaferkocak12@gmail.com 
of many patients do not undergo surgical treatment for the second primary (1-3). We believe that the occurrence of third primary cancer increases with the resection of the second primary lung cancer. In a study by Lee et al., they investigated the incidence of third primary cancers and the results of the surgical therapy in patients with resected stage I second primary lung cancers (3). They reported that the incidence of third primary lung cancers after a second primary is $10 \%$ and half of them undergo surgery. In their study, there was a statistically significant difference in survival between patients treated surgically and non-surgically and patients underwent treatment and those who did not. They concluded that surveillance and intervention at early stage is associated with an improved survival.

Thus, the occurrence of a third primary lung cancer in patients with a history of resected second primary lung cancer is not a very rare phenomenon and a lifelong follow up is important to detect metachronous tumors.

\section{REFERENCES}

1. Fındık G, Hazer S, Aydoğdu K, Küçükbayrak A, Kaya S. The third primary-the second metachronous lung cancer in the same patient. Tuberk Toraks 2012;60:365-9.

2. Flynn MJ, Rassl D, El Shahira A, Higgins B, Barnard S. Metachronous and synchronous lung tumors: five malignant lung pathologies in 1 patient during 7 years. Ann Thorac Surg 2004; 78:2154-5.

3. Lee DS, Taioli E, Kaufman A, Wolf AS, Bhora FY, Ramanathan $S$, et al. Incidence and benefits of surgical therapy for third primary lung cancers. I Clin Oncol 2015;33:15s (Suppl; abstr e18512). 